\title{
Sources of Risk and Management Strategies among Farmers in Rice Post Harvest Management in Niger State, Nigeria
}

\author{
Usman $\mathrm{J}^{1^{*}}$, Jirgi A.J ${ }^{2}$, Ojo M.A ${ }^{3}$, Tiamiyu S.A ${ }^{4}$ \\ ${ }^{1,4}$ National Cereals Research Institute, Badeggi. P. M .B 8, Bida, Niger State. \\ ${ }^{2,3}$ Department of Agricultural Economics, Federal University of Technology, Minna, Niger State.
}

\begin{abstract}
The study examined sources of risk and management strategies among farmers in rice post harvest management in Niger State. The research was undertaken in five Local Government Areas of Niger State, namely Katcha, Lavun, Paikoro, Shiroro and Wushishi. Data obtained for the research was achieved through questionnaires administered to 200 farmers selected using multi-stage sampling techniques. Descriptive statistics was used for data analysis.
\end{abstract}

The study showed that rice post harvest management is carried out by subsistence farmer with average farm size of 2.7ha and are of active productive age of 31-50 years, who have 24 years farming experience in the rice post harvest management. The study revealed that farmers in the study area are affected by production risk, financial risk, human or personal risk, market or price risk and technological risk sources. The farmers have adopted prevention, mitigation and coping with risk as management strategies. Based on the findings the study recommended provision of credit facilities, rice post harvest machineries at subsidized rate, rural infrastructures, cooperative formation, use of extension officer and proper storage facilities.

Keywords—Risk Management, Strategies, Rice, Farmers.

\section{INTRODUCTION}

Rice is consumed regularly in Nigeria's urban and rural areas and is an important staple food crop. Post harvest management is important in agricultural production due to seasonality of production. Rice production is mostly only once a year, and at most twice, in which about $65 \%$ of production comes from the lowland and rainfed though there are double productions in irrigated areas of the northern parts of the country. Moreover, long scarcity period is involved between planting and harvesting of crops, which in addition to low productivity levels has constrained paddy rice availability from own production.

However, this rice post-harvest management has not received the attention it deserves, the reason probably being the assumption that what matters after all is production, and that if success could be achieved at the production level, then there will be more availability of rice both at the household and market levels (FAO, 2006). Farmers in Nigeria not only face many constraints to produce staple crops, but they are also face with risk and grain management challenges after harvest. By not being able to store effectively, most farmers cannot take advantage of price increases that occur during the production cycle. They often shift from sellers to buyer of grain during the storage season (Didier, Jacob, Corinne and Abdoulaye , 2013) The crucial importance of ensuring sustained levels of marketed surplus of rice both in terms of sufficient quantities as well as fair prices cannot be overemphasized if development is to take place in Nigeria rice sector.

Risk therefore occurs because agriculture is affected by many uncontrollable events that are often related to weather, including excessive or insufficient, rainfall, extreme temperatures, insect pests, and diseases etc ( Jirgi, 2013). Rice post harvest management is a high risk business, because of its dependence on human skills, efficiency of machines and clemency of the physical forces of nature. In Nigeria, however, slow rice post harvest development and the developing status of the nation are major reasons why risk-measuring is unpopular and rarely considered. Farmers with access to risk management information and the knowledge to use have the key to profitable and competitive post harvest operations. Several studies were carried in Nigeria on risks sources and management strategies devised by farmers in different staple crops but for rice post harvest management, there are scanty studies. Therefore, the study aimed at evaluating the sources of risk and management strategies among rice post harvest management farmers' in Niger State, Nigeria. 


\section{METHODOLOGY}

\subsection{Study Area}

The study was carried out in Niger State, Nigeria. The State was created out of the then North-Western state in 1976. The State lies between latitude $8^{0} 11^{\prime}$ and $11^{0} 20^{\prime} \mathrm{N}$ of equator, and longititudes $4^{0} 30^{\prime}$ and $7^{0} 15^{\prime} \mathrm{E}$ of equator. Kaduna State and FCT are her borders to the North-East and South-East respectively; Zamfara State borders the North, Kebbi State in the West, Kogi State in the South and Kwara State in the South West, while the republic of Benin along Agwara LGA boarders her North West. It covers an estimated land area of 76,469,903 square $\mathrm{km}$ and the state has a population of 3,945,772 (NPC, 2006). Gwari, Nupe and Hausa are the major ethnic groups in the State.

Niger State experiences distinct dry and wet seasons with annual rain fall ranges between $1,100 \mathrm{~mm}$ to $1,600 \mathrm{~mm}$. The average minimum temperature is about $26^{\circ} \mathrm{C}$ while the average maximum temperature is about $36^{\circ} \mathrm{C}$. The mean relative humidity ranges between 60 percent (January to February) and 80 percent (June to September).The state falls within the guinea savannah vegetation belt, which supports the cultivation of root crops and grains.

\subsection{Data collection}

To achieve the objective of the study, data was collected through primary and secondary source. This was through personal interviews with the 200 selected rice farmers using designed structured questionnaires.

\subsection{Sampling method}

Multi-stage sampling method was used in the study. First stage involved a random selection of two Local Government Areas each from Agricultural zone I \& II and one local Government Area from Zone III. The selected local Governments areas were Katcha and Lavun for Zone I, Shiroro and Paikoro for Zone II and Wushishi for Zone III respectively. Second stage involved random selection of villages from the selected Local Government Areas. Third and last stage involved proportionate selection of farmers in the selected villages based on the required sample size.

\subsection{Analytical techniques}

Data collected were analyzed using simple descriptive statistics such as tables, percentages and average. However, attitudinal scale approach (ASA) was used to measured individual responses. It consists of defining a scale of statements that reflects the respondent's risk sources and management attitude. An aggregate score based on households' responses to a total of " $K$ " number statements (items), each representing a risk sources and management strategy used by each rice post harvest management farmer would be estimated.

Likert's scale, a 5-point rating scale was used to measure an individual's attitude as established Batttacharya (1993) The responses was measured on a 5-point scale. Strongly agree (score of 1) implied the willingness of farmer to adopt the risk management strategy in question (risk aversion). On the other hand, strong disagree (score of 5) indicated a risk taking attitude. In between the two extremes, disagree (score of 2), undecided/neutral (score of 3) and agree (score of 4) were included as alternative responses. The Likert scale was also used by Meuwissen et al. (2001) and Akcaoz and Ozkan (2005).

\section{RESULTS AND DISCUSSION}

The socio-economic characteristics of the farmers are shown in Table 1. The results indicated that farmers mean age was 41, which implies that majority of the farmers are still active and in the productive stage. This finding were similar to that of Okoruwa et al (2002) and Ekong (2010), that age bracket of farmers in Nigeria are between 30-50 years. Moreover, the characteristic of farmer such as age determines his strength and also to some extent his experiences in rice post harvest management.. Table: 1 also revealed that farmers in the study area have the mean of 24 years experience in rice post harvest activities. Ojo, (2012), reported that farming experience of cassava and yam farmers in Niger and Kogi states had average of 24 years farming experience. This implied that the farmers were well experienced in rice farming and post harvest management. 
TABLE 1

SOCIO-ECONOMIC CHARACTERISTICS OF RESPONDENTS IN THE STUDY AREA. (n=200)

\begin{tabular}{|c|c|c|}
\hline Variables & Frequency & Percentage \\
\hline \multicolumn{3}{|l|}{ Age (years) } \\
\hline $20-30$ & 28 & 14.0 \\
\hline $31-40$ & 84 & 42.0 \\
\hline $41-50$ & 65 & 33 \\
\hline $51-60$ & 19 & 10 \\
\hline Greater than 60 & 4 & 2.0 \\
\hline Mean & 41 & \\
\hline \multicolumn{3}{|l|}{ Sex } \\
\hline Male & 153 & 76.5 \\
\hline Female & 47 & 23.5 \\
\hline \multicolumn{3}{|l|}{ Farming experience (year) } \\
\hline Less than 10 & 18 & 9.0 \\
\hline $10-20$ & 74 & 37.0 \\
\hline $21-30$ & 55 & 27.5 \\
\hline $31-40$ & 40 & 20.0 \\
\hline $41-50$ & 9 & 4.5 \\
\hline Greater than 60 & 4 & 2.0 \\
\hline Mean & 24 & \\
\hline \multicolumn{3}{|l|}{ Level of education } \\
\hline Adult education & 33 & 16.5 \\
\hline Primary education & 37 & 18.5 \\
\hline Post primary education & 47 & 23.5 \\
\hline Tertiary education & 16 & 8.0 \\
\hline Non-formal education & 67 & 33.5 \\
\hline \multicolumn{3}{|l|}{ Household size } \\
\hline None & 6 & 3.0 \\
\hline $1-5$ & 60 & 30.0 \\
\hline $6-10$ & 92 & 46.0 \\
\hline $11-15$ & 42 & 21.0 \\
\hline Mean & 8 & \\
\hline \multicolumn{3}{|l|}{ Farm size (ha) } \\
\hline Less than 1.00 & 31 & 15.5 \\
\hline $1.00-1.50$ & 59 & 29.5 \\
\hline $1.51-2.00$ & 40 & 20.0 \\
\hline $2.01-2.50$ & 8 & 4.0 \\
\hline $2.51-3.00$ & 13 & 6.5 \\
\hline Greater than 3.00 & 49 & 24.5 \\
\hline Mean & 2.7 & \\
\hline
\end{tabular}

Source: Field Survey, (2016)

The result shows that non-formal education has the highest percentage of 34 , while post primary education and primary education recorded $24 \%$ and $19 \%$ respectively. Adult education and tertiary education constituted $17 \%$ and 8 respectively. The different educational status of farmers accounts for the differential managerial ability which also determines to some extent the overall success of the farm business. The level of education contributes much for productivity, adoption of new technology and farming techniques. This agrees with the findings of Okoruwa et al (2002 ) and Nmadu, et al, (2012). Tables 1 revealed that farmers have average household size of 8 . The size of household determines the variability in agricultural production and the amount of labour input. The results also showed that farmers in the study area have average farm size of 2.7ha. This was in line with the findings of Ojo, (2012), who recorded 2.84ha and 2.42ha farm size in Niger and kogi states respectively. The size of farm is very crucial in agricultural since it largely determines the output of a farmer. This contrasted the results of Nmadu et al (2012). 
TABLE: 2

RISK SOURCES IN RICE POST HARVEST MANAGEMENT

\begin{tabular}{|c|c|c|c|c|c|c|c|c|c|c|}
\hline \multirow{2}{*}{ Variables } & \multicolumn{2}{|c|}{ SD } & \multicolumn{2}{|c|}{ D } & \multicolumn{2}{|c|}{ UD } & \multicolumn{2}{|c|}{$\mathbf{A G}$} & \multicolumn{2}{|c|}{ SA } \\
\hline & Freq & $\%$ & Freq & $\%$ & Freq & $\%$ & Freq & $\%$ & Freq & $\%$ \\
\hline Pest \&Rodents & 1 & 0.5 & - & - & - & - & 199 & 99.5 & - & - \\
\hline Drought & 1 & 0.5 & - & - & - & - & 199 & 99.5 & - & - \\
\hline Too Much rainfall/flood & - & - & - & - & 48 & 24.0 & 152 & 76.0 & - & - \\
\hline Illness of family member & - & - & - & - & 85 & 42.5 & 115 & 57.5 & - & - \\
\hline Fire incidence & 1 & 0.5 & 12 & 6.5 & 49 & 24.5 & 125 & 62.5 & 13 & 6.5 \\
\hline Changes in Government agricultural policies & & & & & & & & & & \\
\hline Lack of adequate hired labour & 38 & 19.0 & 13 & 6.5 & 88 & 44.0 & 61 & 30.5 & - & - \\
\hline Inadequate family labour & - & - & 13 & 6.5 & 13 & 6.5 & 174 & 87.0 & - & - \\
\hline Market Failure & 25 & 12.5 & - & - & 60 & 30.0 & 115 & 57.5 & - & - \\
\hline Theft & - & - & 24 & 12.0 & 62 & 31.0 & 114 & 57.0 & - & - \\
\hline Communal clash & 1 & 0.5 & 35 & 17.5 & 12 & 6.0 & 152 & 76.0 & - & - \\
\hline Price changes & 1 & 0.5 & 13 & 6.5 & 37 & 18.5 & 149 & 74.5 & - & - \\
\hline Bad weather condition or situation & 12 & 6.0 & 13 & 6.5 & 37 & 18.5 & 138 & 69.0 & - & - \\
\hline Reduced consumption & 1 & 0.5 & 52 & 26.0 & 35 & 17.5 & 112 & 56.0 & & \\
\hline Off-farm activities & 64 & 32.0 & 25 & 12.5 & 49 & 24.5 & 62 & 31.0 & - & - \\
\hline Diseases & 1 & 0.5 & 36 & 18.0 & 13 & 6.5 & 150 & 75.0 & - & - \\
\hline Flood & - & - & - & - & - & - & 200 & 100 & - & - \\
\hline Borrowed cash or kind & - & - & - & - & - & - & 200 & 100 & - & - \\
\hline Insurance of rice farm/store & 1 & 0.5 & 23 & 11.5 & 13 & 6.5 & 163 & 81.5 & - & - \\
\hline Storage System & 89 & 44.5 & 36 & 18.0 & 37 & 18.5 & 38 & 19.0 & - & - \\
\hline Contributions/Adashe & - & - & 25 & 5.5 & 61 & 30.5 & 114 & 57.0 & - & - \\
\hline Cooperative society & 14 & 7.0 & 12 & 6.0 & 61 & 30.5 & 113 & 58.5 & - & - \\
\hline Market information & 13 & 6.5 & 12 & 6.0 & 25 & 12.5 & 150 & 75.0 & - & - \\
\hline Scattered sales & - & - & 23 & 11.5 & 49 & 24.5 & 128 & 64.0 & - & - \\
\hline Damage by animals & 13 & 6.5 & 49 & 24.5 & 75 & 37.5 & 63 & 31.5 & - & - \\
\hline & - & - & 13 & 6.5 & 13 & 6.5 & 174 & 87.0 & - & - \\
\hline
\end{tabular}

Field Survey, 2016., * Multiple Responses Allowed: $S D=$ Strongly disagreed, $D=$ Disagreed, UD = Undecided, AG = Agreed, SA= Strongly Agree 
TABLE: 3

RISK MANAGEMENT STRATEGIES DEVISED TO MITIGATE RICE POST HARVEST LOSSES

\begin{tabular}{|c|c|c|c|c|c|c|c|c|c|c|}
\hline \multirow{2}{*}{ Variables } & \multicolumn{2}{|c|}{ SD } & \multicolumn{2}{|c|}{ D } & \multicolumn{2}{|c|}{ UD } & \multicolumn{2}{|c|}{$\mathbf{A G}$} & \multicolumn{2}{|c|}{ SA } \\
\hline & Freq & $\%$ & Freq & $\%$ & Freq & $\%$ & Freq & $\%$ & Freq & $\%$ \\
\hline I never insure my farm & 48 & 24.0 & 39 & 19.5 & 12 & 6.0 & 75 & 37.5 & 26 & 13.0 \\
\hline I adopt new technology & 51 & 25.5 & 124 & 62.0 & - & - & 25 & 12.5 & - & - \\
\hline I do not have future market & 24 & 12.0 & 50 & 25.0 & 25 & 12.5 & 51 & 25.5 & 50 & 25.0 \\
\hline I do not have formal life insurance & - & - & 24 & 12.0 & 38 & 19.0 & 64 & 32.0 & 74 & 37.0 \\
\hline I practice both improved and traditional techniques & 127 & 63.5 & 49 & 24.5 & 24 & 12.0 & - & - & $\begin{array}{c}- \\
150\end{array}$ & 75.0 \\
\hline Insufficient sustainable income & 12 & 6.0 & - & - & - & - & 38 & 19.0 & 162 & 81.0 \\
\hline Insufficient backup labour & - & - & - & - & - & - & 38 & 19.0 & - & - \\
\hline I use reaper, thresher \& better storage facilities. & 75 & 37.5 & 73 & 36.5 & 52 & 26.0 & - & - & & \\
\hline I never rear animal for complementing my income & & & & & & & & & & 12.5 \\
\hline I practice mixed cropping & 37 & 18.5 & 87 & 43.5 & - & - & 51 & 25.5 & 25 & 31.0 \\
\hline I never sell my rice at market & 13 & 6.5 & 26 & 13.0 & 25 & 12.5 & 74 & 37.0 & 62 & 44.0 \\
\hline I plant rice because is profitable & 1 & 0.5 & 11 & 5.5 & -- & - & 100 & 50.0 & 88 & 76.0 \\
\hline I do not have any other job & - & - & - & - & - & - & 48 & 24.0 & 152 & 38.0 \\
\hline I belongs to farmers'group/association & 25 & 12.5 & 1 & 0.5 & - & - & 98 & 49.0 & 76 & 50.0 \\
\hline I benefit credit from cooperatives/banks & - & - & 26 & 13.0 & 37 & 18.5 & 37 & 18.5 & 100 & 19.5 \\
\hline $\begin{array}{l}\text { 1 benefit credit trom cooperatives/banks } \\
\text { Off-farm income is not important source of income }\end{array}$ & 26 & 13.0 & 73 & 36.5 & - & - & 62 & 31.0 & 39 & \\
\hline & & & & & & & & & & - \\
\hline I do have access to Extension Agents & 50 & 25.0 & 63 & 31.5 & 75 & 37.5 & 12 & 6.0 & - & 12.5 \\
\hline I rely heavily on market information & - & - & 111 & 55.5 & 63 & 31.5 & 1 & 0.5 & 25 & - \\
\hline Nobody else in the household is interested in rice farming & 86 & 43.0 & 64 & 32.0 & - & - & 37 & 18.5 & - & \\
\hline I do use insecticide/ pesticides & & & & & & & & & & \\
\hline I save greater share of my income in bank. & 124 & 62.0 & 64 & 32.0 & - & - & - & - & 12 & 6.0 \\
\hline I never have storage facilities & 63 & 31.5 & 63 & 31.5 & - & 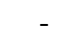 & 61 & 30.0 & 13 & 6.5 \\
\hline I do keep record of my farm & 26 & 13.0 & 61 & 30.5 & 62 & 31.0 & 38 & 19.0 & 13 & 6.5 \\
\hline 1 do keep record or my larm & - & - & 61 & 30.5 & - & - & 77 & 38.5 & 62 & 31.0 \\
\hline I never use improved post harvest operations. & 63 & 31.5 & 63 & 31.5 & 50 & 25.0 & 13 & 6.5 & 11 & 5.5 \\
\hline I do use traditional methods & 26 & 13.0 & 26 & 13.0 & 50 & 25.0 & 98 & 49.0 & - & - \\
\hline I never use traditional pest control systems & - & - & 26 & 13.0 & 13 & 6.5 & 99 & 49.5 & 62 & 31.0 \\
\hline I often fall sick & 36 & 18.0 & 100 & 50.0 & 13 & 6.5 & 25 & 12.5 & 26 & 13.0 \\
\hline Weather is never favourable & 38 & 19.0 & 98 & 49.0 & 63 & 31.5 & 1 & 0.5 & - & - \\
\hline I benefit in government projects & 64 & 32.0 & 86 & 43.0 & 12 & 6.0 & 26 & 13.0 & 12 & 6.0 \\
\hline I have ready market & 13 & 6.5 & 36 & 18.0 & 38 & 19.0 & 13 & 6.5 & 100 & 50.0 \\
\hline I do not have enough money for farming activities & - & - & 12 & 6.0 & 24 & 12.0 & 100 & 50.0 & 64 & 32.0 \\
\hline & - & - & 12 & 6.0 & - & - & 74 & 37.0 & 114 & 57.0 \\
\hline
\end{tabular}

Field Survey, 2016, * Multiple Responses Allowed: SD Strongly disagreed, D-Disagreed, UD- Undecided, AG-Agreed, SA- Strongly Agreed 
The result in Table: 2 show the sources of risks experienced by the farmers in rice post harvest management. Which revealed that diseases outbreak, too much rainfall/flood, pests and rodents attack, drought have $100 \%$ of the respondents, were ranked as sources of risk. While damage by animals, lack of adequate hired labour $87 \%$ of the respondents, borrowed in cash or kind ( $82 \%$ of the respondent), theft ( $76 \%$ of the respondent), off-farm activities , cooperative society and communal clash (75\% of the respondents), were identified also as risks sources encountered by farmers in the study area.. The results also indicated that price changes $(69 \%$ of the respondents), market information ( $64 \%$ of the respondents), fire incidence (63\% of the respondents), contributions or adashe (59\% of the respondents), and family labour, and illness of the family member ( $58 \%$ of the respondents), storage system (57\% of the respondents), bad weather condition (56\% of the respondents) were identified as part of sources of risk in rice post harvest management. This indicated that farmers in the study area are likely affected by the production risk, financial risk, human or personal risk, market or price risk and technological risks. This is similar to the findings of Jirgi (2013), Alimi and Ayanwale (2005) and Ogunniyi and Ojedokun (2012), who reported that farmers are faced with different risk factor in the production, processing and marketing. This may likely be the reason why many farmers turned from producers of the rice to the buyers of the commodity for consumption. While, scattered sales (thirty two percent of the respondents), changes in government policies and reduced family consumption (thirty one percent of the respondents), insurance of rice farm or store (nineteen percent of the respondents) and were identified as not key risk sources in the study area. This also disagrees with the findings of Jirgi (2013), reported government policies as important sources of risk. This implies that farmers also experienced these risk sources but not as serious as the earlier ones mentioned. Risk sources cause adversity in yield, prices and production units. Each or any combination of the outcomes, of the risk sources (bad yield, poor prices, and inadequate production units) leads to poor farm income (Alimi and Ayanwale, 2005)

Table 3 shows risk management strategies devised to mitigate rice post harvest losses according to their importance assessed using a scale from 1 (Strongly disagree) to 5 (Strongly agree). Management of risk required knowledge of the most crucial risk being faced, identifying the impacts and likelihood of undesirable results; and taking possible steps to mitigate impacts. Rice post harvest management is a profitable venture (100\% of the respondents). Farmers who do not sell rice in the market and many household members are interested in rice post harvest management as a business (94\% of the respondents). Farmers who do not have any other job apart from rice production ( $87 \%$ of the respondents), ready market for rice ( $82 \%$ of the respondents.), and weather is favourable for post harvest activities ( $75 \%$ of the respondents). Farmers belongs to cooperative associations (69\% of the respondents), practice of mixed cropping (68\% of the respondents), Farmers used rearing of animals to sell to compliment income from rice production (62\% of the respondents), off-farm income is an important source of income and benefit from government projects (57\% of the respondents), use traditional method of post harvest operations ( $50 \%$ of the respondents), were the major risk management strategies adopted by farmers in the study area to mitigate losses of rice and income. This implies that farmers uses prevention, diversification, mitigation and coping risk management strategies in the study area, which was perfectly in line with the findings of Okunmadewa, (2003), Okereke (2012) and Jirgi (2013), who reported various risk managements adopted by farmers to averted risk.

\section{CONCLUSION}

The study examines sources of risk and management strategies devised among rice post harvest management farmers in Niger State. The study showed that farmers in the study area are affected by production risk, financial risk, human or personal risk, market or price risk and technological risk sources. The farmers have adopted prevention, mitigation and coping with risk as management strategies. The study recommended provision of credit facilities, infrastructural facilities, post harvest machineries, proper storage facilities, extension agents, cottage improved rice processing factories and timely harvesting of rice using appropriate method and threshing and winnowing on cleaned concrete slab or tarpaulin.

\section{REFERENCES}

[1] Akcaoz, H. \& Ozkan, B. (2005). Determining risk sources and strategies among farmers of contrasting risk awareness: A Case Study for Cukurova Region of Turkey. Journal of Arid Environment, 62, 661-675.

[2] Alimi, T. \& Ayanwale, A.B. (2005). "Risk and Risk Management Strategies in Onion Production in Kebbi State of Nigeria". Journal of Social. Science. 10 (1), 1-8.

[3] Battacharya K. (1993). A Study on farmer's participation in farm forestry programme. Unpublished PhD. Thesis, Department of Agricultural Extension, Bidhan Chandra Krishi Vishwavidyalaya, West Bengal, pp- 53-59.

[4] Didier, K. Jacob, R.G. Corinne.A, \& Abdoulaye.T (2013): Effects of Storage Losses and Grain Management Practices on Storage: Evidence from Maize Production in Benin. A Paper Presented at Agricultural \& Applied Economics Association's (AAEA \&CAES) Joint Annual Meeting Washington, DC, August 4-6, 2013. 
[5] Ekong, E. E. (2010). Rural Sociology: An Introduction and Analysis of Rural Nigeria (3rd ed). Uyo: Dove Educational Publishers. Pp. $404-407$.

[6] Food and Agricultural Organization (FAO), (2006). The International Rice Commission, Reducing Post Harvest and Processing Losses, pp1-3.

[7] Jirgi, A.J, (2013), Techinical efficiency and risk preferences of cropping systems in Kebbi State, Nigeria. Unpublished Ph'D Thesis submitted to the Department of Agricultural Economics Faculty of Natural and Agricultural Sciences University of the Free State Bloemfontein, South Africa. Pp.30-176.

[8] Meuwissen, M.P.M., Huirne, R.B.M. \& Hardaker, J.B. (2001).Risk and Risk Management: An Empirical Analysis of Dutch Livestock Farmers. Livestock production science 69, 43-53.

[9] Nmadu, J.N, Eze, G.P, \& Jirgi, A.J, (2012). Determinants of risk status of small scale farmers in Niger State, Nigeria. British journal of economics, management \& trade. 2 (2): 92-108

[10] Nmadu, J.N \& Dankyang, Y. (2015). Sources of Risk and Management Strategies among Small Scale Farmers in Kaduna State, Nigeria.Conference paper at International Interdisciplinary Business-Economics Advancement Conference (IIBA 2015), University of South Florida and Istanbul University, 1-14.

[11] NPC (2006). National Population Commission: State Population in Nigeria, Abuja, Nigeria. http://www.population.gov.ng/index.php?option

[12] Okereke, C.O. (2012). Challenges of Risk Management among Smallholder Farmers in Ebonyi State, Nigeria: Implications for National Food Security. International Journal of Agricultural Economics \& Rural Development - 5 (1), 1-10

[13] Okoruwa, V.O.,Ojo, O.A, Akintola, C.M, Ologhobo, A.D \& Ewete, F.K (2002). Post harvest grain management storage techniques and pesticides used by farmers in south-west, Nigeria. Journal of Economics and Rural Development, 18 (1), 53-72.

[14] Ojo, M.A (2012). Analysis of Production Efficiency among Small Scale Yam and Cassava Farmers in Niger and Kogi States, Nigeria. Thesis submitted for the Partial Fulfilment of the Award of Doctor of Philosophy. Department of Agricultural Economics and Extension Technology. Federal University of Technology, Minna. Pp-74-120

[15] Okunmadewa, F.(2003). Risk, Vulnerability in Agriculture; Concept and Context. A Paper presented at staff seminar, Department of Agricultural Economics, University of Ibadan. 